\title{
The cost efficiency of small farm inclusion in agribusiness supply chains
}

\author{
K Sartorius
}

School of Accountancy, University of the Witwatersrand

\section{J Kirsten}

Department of Agricultural Economics, University of Pretoria

Received: February 2004

SAJAR

Revised: April 2004

Vol 18 No. 1

Accepted: May 2004

The inclusion of small-scale commercial farmers in South African agribusiness supply chains is a national priority and there is an urgent need for managerial accounting (MAS) inputs to successfully accomplish this objective. This paper explores ways that small farmers can be cost effectively incorporated in modern agricultural supply chains. A case study methodology is used to test the research questions. The results demonstrate that small-scale farmers can successfully compete with larger growers with respect to production and cost efficiency. The results also illustrate that small-scale farmers generate higher levels of transaction cost than medium and large scale suppliers. A series of proposals are then developed in order to reduce the transaction cost of small farm supply. In conclusion, smallscale farmers can be successfully incorporated in agribusiness supply chains but only if special measures are taken to reduce differential transaction cost.

\section{KEY WORDS}

agribusiness supply chain, smallholder, production efficiency, transaction cost

\section{Contact}

Kurt Sartorius

sartoriusk@soa.wits.ac.za 


\section{INTRODUCTION}

The "new economy" has witnessed the implementation of strategy in conditions of increasing competition, uncertainty, change, business downturns and new technologies (Merchant, 1998; Anthony \& Govindrajan, 2001; Porter, 2001). Many firms have re-invented themselves, shed non core activities and restructured certain activities outside their traditional boundaries (Widener \& Selto, 1999; LangfieldSmith \& Smith, 2003). A wide range of organisation structures and new management practices have emerged to complement responsive strategy. Despite progress towards understanding institutions, they are still not fully understood because they are complex. Organizations are complex because they are systems that recognise more than one ultimate principal and corporate situations are often simultaneously social and economic (Barney \& Ouchi, 1988; Williamson, 2000). In certain instances, for example, the suitability of organisation structures that have been dictated by firm strategy are contradicted by the transaction characteristics of its activities (van den Bogaardt \& Spekle, 2003). Recent theoretical developments provide an ideal opportunity to apply new approaches to understanding and evaluating the managerial and organisational environment of many industries that are undergoing structural change (Barry et al, 1992). An understanding of the relationship between economic theory and the practice of management accounting is especially important (Burns \& Scapens, 2000) and the role of management accountants is expanding to include the cost implication of organisation structure, issues beyond the firm boundary and value chain information systems (van der Meer-Koistra \& Vosselman, 2000; Spekle, 2001).

The industrialisation of agriculture in many developed countries has also resulted in the restructuring of this sector as a result of the need for continuity of supply and economies of scale. It has been suggested that this feature is likely to be replicated in other parts of the developing world. Smaller operations, not associated with an industrialised system, will have increasing difficulty in gaining the economies of size and the access to technology that is required in order to be competitive. (Kandiwa, 1999; Boehlje \& Doering, 2000; Stanton, 2000; Reardon \& Barrett, 2000). The South African dilemma is that, despite an international trend towards fewer-larger farms, there is an urgent need to transform the agricultural sector by way of the inclusion of smallholders in the commercial farm sector. This dilemma is compounded by a lack of managerial accounting (MAS) research in agricultural supply chains. The purpose of this study is to contribute to the design of cost efficient agribusiness small-farm models with respect to the supply of a raw commodity in an agricultural supply chain.

The problem, in terms of its South African context, is that despite the changes in legislation, small-scale supply operations are largely excluded from many agribusiness supply chains (Machethe et al, 1997; Van Rooyen, 1999; Van Rooyen 
et al, 1999). Moreover, the lack of public finance and the barriers of entry to many value added crop sectors are prohibitive for small-scale farmers. These barriers to entry include the cost of modern production and processing facilities that include high levels of capitalisation, running costs and skills. The removal of these barriers has been compromised by the limited ability of government to rectify the current status quo (Binswanger et al, 1993; Mbongwa et al,1996; Kirsten \& van Zyl,1996; Delgado, 1999; Kirsten \& Sartorius, 2002). The question remains, however, can smallholder suppliers compete with larger producers in terms of production efficiency and do smallholders generate incremental transaction cost for their agribusiness partners in a supply relationship? Furthermore, can agribusiness make the process of dealing with smallholders cost effective and sustainable whilst, at the same time, contributing to poverty alleviation and development?

The research objectives are as follows:

- To determine whether small-scale producers can compete with medium and large scale producers in an agricultural supply chain with respect to the supply of a raw commodity.

- To determine whether small-scale farmers generate higher levels of transaction cost for their agribusiness partner than medium and large scale farmers with respect to the supply of a raw commodity.

The relative lack of empirical studies in Africa underlines the importance of conducting further research (Little \& Watts, 1994; Eicher \& Staatz, 1998) in a continent where it is estimated that some 110 million subsistence farmers exist (Von Braun, 1990). The gravity of the problem is also highlighted by the high level of failure of small-scale farmer contract farming projects in developing countries (Watts, 1994, Little; 1994; Glover,1994; Von Braun \& Kennedy, 1994; Runsten \& Key, 1996; Delgado, 1999). The slow pace of agrarian reform in South Africa since 1994 (Van Zyl \& Kirsten, 1999) has highlighted the urgent need to develop smallscale farm access to commercial farming opportunities (Ministry for Agriculture and Land Affairs, 1998). Finally, the importance of restructuring the agricultural sector in South Africa, in conjunction with land reform, are seen as key measures that need to be addressed in order to modernise the farm sector, as well as achieve greater levels of social equity (Van Zyl, 1996; Kirsten \& van Zyl, 1996).

The remainder of the paper is as follows. Section Two discusses the managerial economics of small farm supply. Section Three outlines the methodology and data. Section Four introduces a case study in the sugar and timber industries of Southern Africa. Sections Five and Six test the two research questions. Section Seven develops a summary and conclusion to the study and suggests some directions for 
future research efforts and, finally, Section Eight outlines a series of recommendations.

\section{THE MANAGERIAL ECONOMICS OF SMALL-SCALE FARMER SUPPLY}

A history of smallholder supply reveals that agribusiness have often preferred dealing with larger farmers in order to reduce transaction costs and because of the need for greater consistency of quality and supply (Runsten \& Key, 1996; Key \& Runsten, 1999). However, considerable literature indicates that small farm systems can be more efficient than large farms. There is thus, a dilemma between productivity, farm size, and the incidence of transaction cost.

\section{Productivity}

Productivity is defined as the ratio of output to input or alternatively input to output. It is measured either in terms of physical units called physical productivity or in monetary units called value productivity (Han, 1991). Productivity is a function of technical efficiency, scale efficiency and allocation efficiency (Livio \& Massimo, 2002). Technical efficiency is determined on the basis of the maximum output given certain inputs or alternatively as the minimum inputs to achieve a given output. Allocative efficiency compares the observed mix of inputs or outputs with the optimal mix that would minimise cost, maximise profit or obtain other behavioural goals. Finally, scale efficiency involves a comparison of the optimal and observed size of the firm (Wheelock \& Wilson, 1995). Accounting productivity measures include short versus long term measures, financial and non financial indicators and variance analysis. These measures typically include some type of input-output ratios that are of both a financial and non financial ratio. Typically, cost in relation to production output is used as a measure of performance, as well as a range of non financial measures like output per bour and per area (Drury, 1996;Drury \& Tayles, 1998; Kaplan \& Atkinson, 1998; Horngren et al., 1999). Ittner and Larcker (1998) summarise accounting measures of productivity or efficiency to include earnings per share (EPS), return on investment (ROI), economic value added (EVA) and cash flow return on investment (CFROI). Limitations in these traditional accounting based performance measures have resulted in the use of comprehensive performance measures like the "balanced scorecard" (Kaplan \& Norton, 1992).

Various models like the Leontief input-output model and the Koopmans Activity model measure productivity by way of employing matrix algebra and constrained optimisation techniques to develop standard outcomes for a given set of inputs. In this fashion actual outputs can be compared to standard outputs with respect to a given set of inputs (Han, 1991). Data envelopment analysis (DEA), illustrated in 
Figure 1, is a non-parametric methodology in which linear programming is used to measure the difference between actual and optimal performance (Wheelock \& Wilson, 1995). DEA can be used to measure the efficiency of the firm given the existence of multiple inputs and outputs (Rouse et al, 2002; Livio \& Massimo, 2002). In this example five decision making units $A, B, C, D$ and $E$ have produced outputs (in relation to inputs) where A, C and B (100\%) are situated on the optimum efficiency frontier. Conversely, D (90\%) and E (70\%) are inside the boundary area indicating less efficient use of inputs. DEA is an excellent tool for benchmarking providing not only an efficiency score ( $70 \%$ for $\mathrm{E}$, for example) but also a target optimal value and benchmarks of efficient performers $(A, C, B)$. By applying Malmquist techniques the optimal frontiers with respect to the solution can be adjusted to accommodate the experience curve and changes in technology (Rouse et al, 2002).

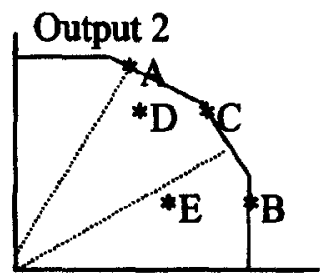

Output 1

Figure 1: Actual versus Optimal Efficiency Frontiers

\section{Farm size and efficiency}

The argument for developing large farms has its roots in Marxian philosophy where it was believed economies of scale could only be achieved for large state or collective type farming systems involving a degree of mechanisation (Binswanger \& Elgin, 1992). A number of arguments support this philosophy. Management skills, together with modern technology, also give rise to increased farm size and despite the fact that these skills can be hired they are still considered to be "lumpy inputs" that tend to adjust farm size upwards. Recent trends in farm size suggest the need for larger farms in agricultural supply chains because of the need for continuity of supply and homogeneity of quality. (Binswanger \& Elgin, 1992; Binswanger et al, 1993). The result of this trend is the concentration and specialisation of farming in fewer larger farms (Schrader, 1986; Frank \& Henderson, 1992; Rhodes, 1993; Ling \& Liebrand, 1995; Pasour, 1998). Other arguments in favour of a positive relationship between size and increased efficiency include technology that is 
designed for large farms (Carter \& Mesbah, 1993) and the fact that larger farms have better access to credit (Carter \& Wiebe, 1990; Binswanger et al, 1993).

The argument that smaller farms are more efficient has been widely supported in a number of empirical studies. In a study of 117 countries higher levels of productivity were recorded in smaller farms (Van Zyl, 1996) and another survey in Brazil, Pakistan and Malaysia also concluded that small-scale family farms were more productive than large farms (Binswanger \& Elgin, 1992). The major reason for higher levels of efficiency is assumed to be because of the higher productivity of farm family labour allied with the facility of rental markets which reduce technical disparities. Conversely, the higher cost of labour on larger farms is due to supervision and recruitment costs (Binswanger \& Elgin, 1992; Van Zyl, 1996). In South Africa, in particular, it has been argued that farm size has been artificially inflated by decades of colonial and apartheid policy that has created cheap access to subsidies and credit (Fenyes et al, 1988; Kirsten \& Van Zyl, 1996).

\section{The lessons of small-scale supply}

The international lessons of promoting successful small farmer agribusiness supply arrangements have been well documented. Kirsten and Sartorius (2002) suggest the problems of contract farming in developing countries can be summarised largely in terms of two issues, namely, the enforcement of contracts and the high level of transaction cost of dealing with small-scale farmers. The main lessons that emerge from this experience are that:

- The farmer partners should be properly screened and selected on the basis of ability rather than merely to redress past injustice.

- Commoditics requiring more labour intensive production techniques and that enjoy economies of scale in the processing phase of operations are more suited to small farm participation.

- Mutual asset specificity between the contracting partners should be incorporated, as these raise the exit costs for both partners and therefore ensure a more stable and sustainable relationship.

- The logistics of the supply chain should be carefully planned in the start-up phase of operations so as to minimise distance and cost.

- The formation of farmer co-operatives is seen as the most cost effective way to represent the interests of the contracted farmer and agribusiness. 


\section{THE METHODOLOGY AND DATA}

A case study in the sugar and timber industries of South Africa has been employed to test the two research objectives, namely, whether small farms can compete with larger growers in terms of production and cost efficiency and whether or not small farmers generate incremental transaction cost to their agribusiness partners. A case study approach was employed because of the qualitative nature of the data and because of the need to explore a wider range of variables that affect the performance and inclusion of small-scale farmers in a supply chain. The Sugar and timber industries were specifically selected for two reasons. Firstly, both of these sectors incorporate the widespread inclusion of small-scale suppliers. In the last decade the timber industry in Southern Africa has promoted in excess of 18000 small-scale suppliers and the sugar industry over 100000 small-scale sugar growers. Both industries, moreover, have developed strategic plans to significantly expand smallscale growers as a source of supply. Secondly, a feature of timber and sugar supply chains in Southem Africa is that small-scale growers have competed for many years with both company plantations and medium-large farmers. Because of a combination of these factors, a considerable data base of small farm activities has been developed. Finally, small, medium and large growers in the sugar industry are categorised as growers occupying 10 hectares or less (small), growers farming between 10-100 hectares (medium) and growers whose capacity is greater than 100 hectares (large). It should be noted that even though small-scale farmers are co-ordinated by way of farmer associations the collective size of these entities are still small compared to larger operators. A large number of families, moreover, operating within the farmer association, result in a collection of small farms rather than one large farm and economies of scale are limited. In this context the farmer association is able to overcome certain individual constraints but only to a limited degree. Conversely, small, medium and large growers in the timber industry are categorised as growers occupying 1 hectare or less (small), growers farming between 10-50 hectares (medium) and growers whose capacity is greater than 50 hectares (large). No farmers association currently exists to co-ordinate small-scale growers in the timber industry.

The first research question was tested by comparing the production and cost efficiency of the different suppliers. In terms of Section 2.1 production efficiency for the first case study has been measured on the basis of a combination of yield per hectare and the sucrose percentage yield per ton of sugarcane crushed. In the case of the second case study productivity has been measured on the basis of the mean annual equivalent of timber grown. This measure estimates the volume in cubic metres of timber grown per hectare per annum for the various growers. In terms of Section 2.1 the cost efficiency of production was developed as follows for both case studies. Total cost per ton of sugarcane and timber delivered to the processor was developed for a five year period for each of the different categories of supplier, namely, small, medium and large. A qualitative argument, based on the costing data, 
was then developed to examine and compare the cost efficiencies of smallholder versus larger supplier production efficiency. The second research question was tested by examining the historical records of the companies to ascertain whether the transaction costs of smaller suppliers were different from that of larger suppliers. More specifically, three types of transaction cost were examined, namely, start-up cost, growing-delivery transactions and administration transactions. With respect to each category of transaction cost a qualitative argument was then developed, in conjunction with supporting evidence, to test whether smallholder transaction cost exceeded that of larger suppliers.

The data for the first case study (sugar) consist of the historical records of the Mhlume Sugar Company (MSCo), Swaziland, the Transvaal Sugar Company (TSB), Malelane, South Africa and the South African Cane-growers Association (SACA), Kwazulu-Natal, South Africa. The data also include the records of a number of farmers' associations that are contracted to supply sugarcane to the MSCo and TSB companies. The data from these organisations consist primarily of the historical records of the MSCo company and it's contracted growers between 1996 and 2001. The data were collected on a number of field trips between June and December 2001. The limitations of the data are primarily the incomplete nature of the financial records of the small-scale farm associations. The data for second case study (timber) are located at Sappi-Saicor, Umkomaas, South Africa, Sappi Forest Division in Pietermaritzburg, South Africa and at Forestry Economic Services (Pty) Ltd in Pietermaritzburg and Johannesburg, South Africa. The data for Project Grow timber farmers are located at Sappi Forest division and the Lima Rural Development Foundation in Pietermaritzburg, South Africa. The data from these organisations consist primarily of the historical records of the Sappi-Saiccor company and it's contracted growers between 1995 and 2001.

\section{THE CASE STUDY}

\section{Background}

The sugar and timber industries play an important role in the economy of both South Africa and Swaziland. Sugar production in Swaziland employs 20000 people and accounts for $60 \%$ of the agricultural gross domestic product Conversely, in 2000/1 the sugar industry in South Africa directly employed 85000 workers and contributed R 1.9 billion to the country's foreign exchange earnings. The forestry industry consists of two primary segments, the growing of timber which falls into the forestry sector and the processing of timber which falls into the manufacturing sector. The timber industry in South Africa contributed a total of $2 \%$ of the total national gross domestic product in 2000/1. 


\section{The companies}

The sugar producing companies incorporated in the case study include the Mhlume Sugar Company (MSCo) of Swaziland and Transvaal Sugar Limited (TSB) of Mpumalanga, South Africa. A limited number of financial indicators are included in Table 1 because of the presence of a secrecy agreement with respect to the one company. MSCo produces a number of sugar products including raw brown sugar, refined sugar and molasses. Transvaal Sugar Limited (TSB) was founded in 1965 and operates in the province of Mpumalanga, South Africa. TSB is a $100 \%$ owned subsidiary of Hunt Leuchars and Hepburn (HL \& H) which, in turn, forms part of the Rembrandt Group of companies. The current estimated replacement value of total company assets is $R 2.3$ billion.

Table 1: Financial indicators

\begin{tabular}{l|c|c|c}
\hline \multicolumn{1}{c|}{ Financlal Indicators } & $\begin{array}{c}\text { Mhlume Sugar } \\
\text { (MSCo) }\end{array}$ & $\begin{array}{c}\text { Transvan } \\
\text { Surar (TSD) }\end{array}$ & Sappl-Salccor \\
\hline $\begin{array}{l}\text { Return on Capital Employed } \\
\text { (ROCE) }\end{array}$ & $82 \%$ & $\begin{array}{c}\text { N/A (secrecy } \\
\text { agreement) }\end{array}$ & $88 \%$ \\
\hline Annual Turnover & R 351 million & $\begin{array}{c}\text { N/A (secrecy } \\
\text { agreement) }\end{array}$ & R 2.85 billion \\
\hline Profit before Tax & R 107.8 million & $\begin{array}{c}\text { N/A (secrecy } \\
\text { agreement) }\end{array}$ & R 1.16 billion \\
\hline Assets Employed at current cost & R 2 billion & R 2.3 billion & R 5 billion \\
\hline
\end{tabular}

\section{The growers}

\section{Sugarcane}

The major categories of grower include the company estates, contracted small-scale farmers and contracted medium to large growers. Whilst the MSCo estates currently grow $67 \%$ of sugarcane processed and contracted growers $33 \%$, the TSB estates produce only $18 \%$ of sugarcane processed with $82 \%$ supplied by contracted farmers. In both instances, contracted small-holders supply $18 \%$ of sugarcane requirements.

\section{Timber}

Three principal categories of grower supply timber to the Sappi-Saiccor mill. These growers include the plantations of the Sappi Forest division, medium to large contract growers and a managed smallholder scheme (Project Grow). Sappi Forest 
Division oversees the production and delivery of all timber to the Sappi-Saiccor mill. Sappi Forest, as a grower, owns and manages 500000 hectares of plantations in Southern Africa that primarily grow eucalyptus and softwoods. The second category of grower consists of medium size contracted suppliers operating on family farms in excess of fifty hectares. These growers are largely autonomous with respect to the growing of timber but the felling and delivery operations are controlled and co-ordinated by Sappi Forest Division. The third category of grower includes 7000 managed small-scale farmers incorporated in Sappi's Project Grow program. This category of micro-grower, occupying an average of 0.6 hectares, is, mostly located within a one hundred kilometre radius of the company mill.

\section{THE COST EFFICIENCY OF SMALL-SCALE PRODUCTION IN SUPPLY CHAINS}

\section{The sugar industry}

The production and cost efficiencies of the sugar growers between 1996-2001 are reflected in Table 2 in terms of the yield per hectare and the average cost per ton standardised at 1999 prices is recorded in South African rand per metric ton (R/Mt). This data is presented for Mhlume Sugar Company (MSCo), the Transvaal Sugar Company (TSB) and small-scale grower associations supplying these two companies. Small-scale grower associations supplying MSCo are listed as M-SF1, M-SF2 and M-SF3 and small-scale growers supplying TSB are listed as T-SF1, TSF2 and T-SF3. The data indicating production efficiency includes total cane produced in metric tons, as well as the sucrose percentage and the yield in metric tons per hectare.

Table 2: Comparative grower performance: Sugar

\begin{tabular}{|c|c|c|c|c|c|c|c|c|}
\hline & $\begin{array}{l}\text { MSCo } \\
\text { Dotute }\end{array}$ & $\begin{array}{l}\text { MSCo } \\
\text { M-SF } 1\end{array}$ & $\begin{array}{l}\text { MSCo } \\
\text { M-SF2 }\end{array}$ & $\begin{array}{l}\text { MSCOM- } \\
\text { SF3 }\end{array}$ & $\begin{array}{l}\text { TSB } \\
\text { Estate }\end{array}$ & $\begin{array}{l}\text { TSB } \\
\text { TSSFI }\end{array}$ & $\begin{array}{l}\mathrm{TSB} \\
\mathrm{T}-\mathrm{SP2} \\
\end{array}$ & $\begin{array}{l}\text { TSB } \\
\text { TSSB }\end{array}$ \\
\hline Are (hectares) & 8302 & 203 & 1277 & 47 & 7260 & 38 & 857 & N/A \\
\hline \multicolumn{9}{|l|}{$\begin{array}{l}\text { Production } \\
\text { Expintancy }\end{array}$} \\
\hline Cane (Mt) & 3343675 & 74744 & 372232 & 5873 & 696583 & 4124 & 84912 & N/A \\
\hline Sucrose & 484247 & 10305 & N/A & 793.1 & 87401 & 567 & 11790 & N/A \\
\hline Sucrose $\%$ & 14.48 & 13.8 & $\mathrm{~N} / \mathrm{A}$ & 13.5 & 12.5 & 13.8 & 13.9 & N/A \\
\hline Yield & 100.7 & 122.7 & 97.2 & 125.0 & 96 & 109 & 99 & $\mathrm{~N} / \mathrm{A}$ \\
\hline Coul Duliciency & RMt & R/Mt & R/Mt & R/M: & $\mathrm{R} / \mathrm{Mt}$ & $\mathrm{R} / \mathrm{Mt}$ & $\overline{\mathrm{RMAt}}$ & RMt \\
\hline Cultivating & 30 & 38 & 26 & 41 & 46 & 51 & 59 & 55 \\
\hline Harventing & 29 & 25 & 27 & 31 & $\overline{34}$ & 38 & 30 & 32 \\
\hline Replanting & 12 & 5 & 0 & 0 & 5 & 8 & 8 & 9 \\
\hline Operatine Costs & 71 & 6 & 53 & $\overline{72}$ & 86 & 97 & 97 & 96 \\
\hline Overheads & 3I & 12 & 23 & 14 & 27 & 13 & 13 & 13 \\
\hline Total Cos & 102 & 6 & 76 & 86 & 113 & 110 & 110 & 110 \\
\hline Net Incorne/ha & 7734 & 10920 & 9040 & 9750 & 2594 & 3815 & 2180 & N/A \\
\hline
\end{tabular}


The sucrose percentage indicates the quality of sugarcane produced in terms of the amount of sucrose obtained per ton of sugarcane processed. The data illustrating the cost efficiency of production includes a full breakdown of operating cost including the activities of cultivating, harvesting and replanting, as well as data that records overhead costs. The small-scale farmers appear to, mostly, outperform the company estates with respect to the yield in metric tons per hectare for irrigated sugarcane. The growers all employ a similar production technology in a crop sector that requires certain economies of scale. In the case of the Swaziland company (MSCo) the small-farm grower yield was between $97 \%$ and $124 \%$ of company performance and the yield for two out of the three sample groups of small-scale farmers was between $122 \%$ to $124 \%$ more than the company estate. In support of the high level of production efficiency of the Swaziland small-scale growers the South African case study indicates similar results. In the case of the South African company (TSB) small-farm grower yield ranged between $103 \%$ and $113 \%$ of company yield. Smallscale growers also competed well in terms of the quality of sugarcane grown. The sucrose percentage yield for Swaziland small growers was between $93 \%$ and $95 \%$ of company performance whilst their South African counterparts enjoyed sucrose percentage yields of between $110 \%$ and $111 \%$ of company yield. The irrigated sugar industry in Southem Africa is highly competitive with both regional and international players. Between 1995 and 2000, Swaziland growers produced a yield per hectare of between 95 and 100 metric tons with an average sucrose content of $14 \%$. By comparison the irrigated sugar industry in South Africa produced a yield of 98 metric tons per hectare with an average sucrose yield of $13.8 \%$. This level of productivity compares well with the irrigated cane sectors in Southem Africa where Zimbabwe, historically (at least until 2001), produced a yield of 115 metric tons per hectare and a sucrose yield of $14 \%$, whilst Malawi has produced a yield of 95 metric tons per hectare and a sucrose yield of $14 \%$.

In terms of total production cost efficiency the small-scale farmers appear to compete favourably with the company estates of both companies. Whilst the company estates of MSCo and TSB appear to compete effectively with small farmers with respect to operating cost at $R 71$ and $R 86$ per ton respectively, they appear less competitive with respect to the management of facilities costs. Small growers appear to incur much lower levels of overheads than the company estates of both MSCo and TSB who display a very similar overhead cost per ton at R 31 and $R$ 27 respectively. Only M-SF2, which is a managed smallholder project, displays higher levels of overhead at R 23 per ton. The reason for the higher level of company overhead cost in both supply chains is because the companies incorporate numerous support facilities in their agricultural divisions. MSCo agricultural support facilities, for instance, include a laboratory, harvesting services, garage facilities, a transport fleet and an irrigation department. By contrast, small-scale farmers appear to incur lower levels of cost for these facilities because they only contract for them when they are required. It has been suggested that the Swaziland small-scale growers 
are more autonomous and have been producing for longer periods than their South African counterparts. Moreover, Swaziland receives preferential tariffs from the EU and US markets. This seems to be reflected in the lower cost per ton of the Swaziland small farmers than their South African counterparts. Both sets of smallscale suppliers, however, appear to compete favourably with the agricultural divisions of their agribusiness partners.

\section{The timber industry}

The production and cost efficiencies of the timber growers between 1996-2001 are reflected in Table 3 and standardised at 1999 prices. A range of eucalyptus growers supplying the Sappi-Saiccor Company was selected. Large growers (Large) include the Sappi plantations of Umkomaas and Richmond. The cost data for medium size contracted growers (Medium) include the results of a workshop held in May 2001 where the results of 61000 hectares of farmland were consolidated. The Project Grow small-scale farmer cost data (Small) are the result of an analysis of the performance of 98 farmers between 1991 and 2001. Lastly, general data for Kwazulu-Natal and South Africa (Regional), also restated in terms of 1999 prices, have been included for comparative purposes.

Table 3: Comparative grower performance: Timber

\begin{tabular}{|c|c|c|c|c|c|c|}
\hline $\begin{array}{c}\text { Grower Cost } \\
\text { and Revenuse } \\
\text { Date }\end{array}$ & $\begin{array}{l}\text { LARGL } \\
\text { Jmlomas }\end{array}$ & $\begin{array}{c}\text { LARGE } \\
\text { Rdchmond }\end{array}$ & MEDIUM & $\begin{array}{l}\text { SMALL } \\
\text { Prolect } \\
\text { Grow }\end{array}$ & $\begin{array}{l}\text { REGIONAL } \\
\text { Natal }\end{array}$ & $\begin{array}{c}\text { REGIONAL } \\
\text { SA }\end{array}$ \\
\hline Actual tons & 99683 & 219531 & 569115 & 4583 & 1554823 & 4322634 \\
\hline $\begin{array}{l}\text { PRODUCTION } \\
\text { EFICILNCY }\end{array}$ & MAL/a & MAI/: & MAI/ha & MAIRe & MAl/hn & MAL/ha \\
\hline $\begin{array}{l}\text { Mean Annual } \\
\text { lncrement per } \\
\text { hectare }\end{array}$ & 12.90 & 13.10 & 19.15 & 11.00 & 13.80 & 14.08 \\
\hline $\begin{array}{l}\text { Planned Age at } \\
\text { Clear-felling }\end{array}$ & 10.00 & 10.00 & 8.9 & 9.1 & 9.3 & 9.7 \\
\hline $\begin{array}{l}\text { COST } \\
\text { DFFICIENCY }\end{array}$ & R/ton & Reton & R/tan & R/ton & Rhen & Rten \\
\hline Establishment & 8.19 & 11.01 & 9.31 & & 12.03 & 14.43 \\
\hline Tending & 11.07 & 7.58 & 8.92 & & 12.59 & 12.33 \\
\hline $\begin{array}{l}\text { Forest } \\
\text { Protection }\end{array}$ & 23.08 & 20.57 & 11.15 & & 18.33 & 18.11 \\
\hline Harvesting & 39.04 & 38.83 & 42.27 & & 40.91 & 38.46 \\
\hline Transport & 50.33 & 55.99 & 43.99 & & 58.14 & 61.66 \\
\hline Operating Cost & 131.71 & 133.98 & 115.64 & 131.00 & 142.00 & 141.99 \\
\hline Overheads & 39.13 & 35.33 & 30.70 & 36.00 & 45.51 & 44.85 \\
\hline $\begin{array}{l}\text { Total Production } \\
\text { Cost }\end{array}$ & 170.84 & 169.31 & 146.34 & 167.00 & 187.51 & 186.84 \\
\hline
\end{tabular}


Micro grower production efficiency appears to be lower than the company plantations as well as other larger contracted growers. The mean annual increment of micro growers is some $57 \%$ of contracted medium growers and between $83 \%$ and $\mathbf{8 5} \%$ of the Sappi Plantations of Richmond and Umkomaas. In terms of production cost efficiency the micro grower operating cost per ton is competitive with both the Sappi Plantations of Richmond and Umkomaas as well as the regional and national averages. Project Grow production performance is between 1.1-2.3\% more efficient than the Sappi plantations and $10.6 \%$ more efficient than the regional-national averages. By contrast, the contracted medium growers' operating costs are some $12.2 \%$ to $13.6 \%$ below Sappi plantation costs and $18.2 \%$ to $18.5 \%$ below the regional and national average largely because of lower forest protection costs, competitive tending costs and lower overhead costs. Contracted medium farmers' overhead costs are also $13.1 \%$ to $21.5 \%$ lower than Sappi plantations and $31.5 \%$ to $32.5 \%$ lower than the regional and national averages. The principal reason for the competitive overhead cost structure of medium growers is because many services and facilities are contracted out. Project Grow (micro farmers) overhead costs, by contrast, appear to be as high as the Sappi plantations, despite the fact that a majority of forestry services-facilities are contracted. The principal reason for the high level of overhead cost is because of the project is centrally managed by a professional nural management company, as well as by Sappi Forest Division.

\section{Small farm production and cost efficiency}

The production and cost efficiency of small growers in the sugarcane sector appears to compete effectively with both the MSCo and TSB company estates and the Swaziland Growers appear to outperform their South African counterpart in terms of cost efficiency. This performance has been maintained over a five year period and suggests that smaller growers can be economically incorporated in sugarcane supply chains. In the timber industry the grower results indicate that contracted medium growers have the lowest cost of production. The performance of the Project Grow farmers, although less efficient than the contracted medium sized growers, appears to be at least comparable to the Sappi plantations and slightly more cost efficient than the regional and national averages. On the basis of the results, it can be concluded that small-scale farmers can compete with larger suppliers in certain agricultural supply chains. This conclusion is strengthened by the fact that both sugarcane and timber are not particular labour intensive commodities as these sectors favour economies of scale in the production phase. Finally, the sugar study indicated that small-scale farmers are far more competitive with larger growers than their counterparts in the timber industry where production is an ancillary activity that is carried out on too small a scale (average 0.6 hectare). 


\section{THE DIFFERENTIAL TRANSACTION COST OF SMALL-SCALE SUPPLY}

The supply of sugarcane and timber in the two industry sectors generates transaction cost in the start-up phase of operations, the growing-delivery activities and as a result of the administration of growers affairs. Transaction cost is described as the cost of acquiring goods or services across a technologically separable interface where these interactions occur as a result of technology, the division of labour, locations, markets or people.

\section{Start-up transactions}

Start-up transaction cost, largely, includes the development of raw commodity production capacity. These costs include the activities of selection, contract development and training. Larger farmers require little training and because of their size contract development costs are low. Conversely, smaller farmers require much higher levels of inputs. In the sugar industry it was estimated, for example, that some $R$ 600, 000 start-up cost was incurred over a three year period by MSCo and the Swaziland government in order to establish a fifty family farmer association called Nyakafto. Similarly, Transvaal Sugar operates a separate division largely for the benefit of developing small-scale farmers with an annual budget of $R 3$ million. Both MSCo and TSB employ a fulltime development officer-department to establish small-scale sugarcane suppliers whilst private and larger scale suppliers largely self develop their capacity to grow sugarcane. Small-scale farmer start-up transactions are also greater than those relating to larger growers because this category of grower needs to be guided through every phase of obtaining-preparing the documentation for the supplier contract.

In the timber industry, Sappi Forest invested R 10 million in start-up costs and loans for their Project Grow program involving 7000 micro farmers. This project, moreover, has required nearly a decade of committed inputs and periodic payments have been made to the small-scale growers to ensure the planting and maintenance of woodlots are financed. Currently, the management of the project has been contracted out to a rural development organisation (Lima). The micro farmers also require incremental assistance to register as growers and establish growing capacity. By contrast, larger suppliers self develop capacity. Some ten transactions are incurred by Sappi Forest in order to register a standard contract with a prospective contract grower, whether large or small. The Project Grow farmers generate an additional twenty transactions because they are assisted to obtain a water license, secure permission of local and traditional authorities and to record their plots on a geographical positioning system. Larger farmers, on the other hand, establish their own facilities, legality and water license. 


\section{Grower transactions}

Smallholder grower transactions recorded in the timber case study, illustrated in Table 4, are incurred as a result of training requirements, technical inputs, the transport and delivery of seedlings and financing requirements. Medium and larger farmers are largely autonomous with respect to the growing of timber. Conversely, the contracted small-scale growers generated an average of 3.7 transactions per hectare for the year 2000/1. Each smallholder is visited at least twice per year, and six times per year in the planting phase. Fertiliser and chemicals are also dispensed from five different locations in the Project Grow area. The number of plantinggrowing transactions per farmer-hectare has decreased because the average age of the plantations has increased. By contrast, the number of transactions per hectare per year for medium-large growers is less than one, illustrating the increased cost of dealing with micro growers. Project Grow farmers also generate incremental transaction costs in the harvesting operation because of the high level of supervision involved. Lima, the managing agent, is paid a fixed fee per ton to manage the harvesting and transport of Project Grow timber. The incremental level of transaction costs is incurred to help farmers contract with harvesting-transport agents and to ensure that the necessary documentation is facilitated.

Table 4: Project Grow Transaction Volume

\begin{tabular}{l|c|c}
\hline Year & $\begin{array}{c}\text { Project Grow: Transactions/ } \\
\text { hectare/annum }\end{array}$ & $\begin{array}{c}\text { Medium-Large growers } \\
\text { Transactions/ hectare/annum }\end{array}$ \\
\hline 1996 & 6.5 & $<1$ \\
\hline 1997 & 5.3 & $<1$ \\
\hline 1998 & 4,4 & $<1$ \\
\hline 1999 & 3.9 & $<1$ \\
\hline 2000 & 3.9 & $<1$ \\
\hline 2001 & 3.7 & $<1$ \\
\hline
\end{tabular}

*Source: Sappi-Saiccor Case Study

Lima manages the entire process and ensures that the selected growers supply, and are paid for, the correct volume of timber and that the necessary access roads are available. By contrast, medium and large-scale farmers do not need assistance from Sappi Forest for this activity and engage and pay for their own contracted services.

\section{Administration transactions}

A sample of comparative administration transaction cost for both sugarcane and timber production in the case studies is illustrated in Table 5. The transaction cost of administration is listed in terms of a ratio. For example, the cost of dealing with a 
large supplier versus a small supplier in the MSCo supply chain is 0.06: 1.04 . Alternatively, smaller dealers generated one accounting transaction for every 98 tons delivered whilst large suppliers only generated one accounting transaction for every 1528 tons supplied. Table 5 , therefore, illustrates comparative costs only and these could not be calculated in monetary terms. In both sugar companies larger suppliers deliver more tons of sugarcane per accounting transaction generated. The reason for this is that smallholders deliver smaller volumes of sugarcane per week in addition to making more use of company inputs and services. Small-scale suppliers generate between twelve and seventeen times more administration cost than larger suppliers in the sugarcane supply chain. In the timber supply chain the micro growers generate between 0.7 and 3.5 times more cost than the company plantations and medium size suppliers respectively

Table 5: Comparative administration transaction cost per ton

\begin{tabular}{|c|c|c|c|}
\hline & Small & Medium & Large \\
\hline $\begin{array}{l}\text { Sugar: } \\
\text { MSCo }\end{array}$ & $\begin{array}{c}1.04 \\
98.9 \text { tons } / \text { transection }\end{array}$ & N/a & $\begin{array}{c}0.06 \\
1528 \text { tons/transaction }\end{array}$ \\
\hline TSB & $\begin{array}{c}2.00 \\
57 \text { tons/transaction }\end{array}$ & $\mathrm{N} / \mathrm{a}$ & $\begin{array}{c}0.16 \\
613 \text { tons/ transaction }\end{array}$ \\
\hline Timber :Sappi & $\begin{array}{c}>2.6 \\
<3.87 \text { tons/transaction }\end{array}$ & $\begin{array}{c}0.74 \\
13.86 \text { tons/transaction }\end{array}$ & $\begin{array}{c}1.85 \\
5.57 \text { tons/transaction }\end{array}$ \\
\hline
\end{tabular}

*Source: MSCo, TSB and Sappi-Saiccor Case Studies

\section{Small farm transaction cost}

The case study indicates that small-scale growers generate higher levels of start-up transaction cost for their agribusiness partner because of the high level of company inputs that are required to establish production capacity for this category of farmer. Conversely, larger growers require little assistance with respect to contract establishment, technical inputs and the acquisition and management of finances. Similarly, with respect to the growing-harvesting-delivery activities, the micro growers in the timber case study required many more visits and inputs than the larger suppliers. Conversely, the reasonably well managed farmer associations in the sugar sector ensured that there was a comparative level of this type transaction cost with larger suppliers. Finally, the results of the case study suggest that small-scale producers generate a higher level of administration cost because of the smaller volume of deliveries allied to greater use of company facilities. In many instances, moreover, the incremental administration costs extends to the active management of growers financial affairs. In conclusion, small-scale farmers appear to generate incremental transaction cost for agribusiness in both the sugarcane and timber industries. 


\section{SUMMARY AND CONCLUSION}

The paper commenced by identifying the problem of small-scale farmer exclusion in the South African commercial farm sector before discussing the issue of productivity, farm size versus efficiency and the international lessons of smallholder contract farming. A case study in the sugar and timber industries was then employed to test the two research questions. The results of the case study, with respect to the first research question, mostly suggest that smaller growers can effectively compete with larger growers and company estates on a long term basis. These findings, which are widely supported empirically in Section 2, can be used as a basis to convince agribusiness that small-scale growers can operate as viable business partners or, alternatively, as a basis to persuade state-donor bodies that the economic wealth of agricultural supply chains is not adversely influenced by the presence of smallholder production. This finding could also be used as a basis to efficiently unbundle company estates and promote the transformation of the agricultural sector. The results of the two sugar case studies are especially encouraging because these farmers have competed with larger growers in a commodity sector that relies on partial economies of scale. The reason for smallholder competitiveness in the sugar industry is not because of the productivity of family labour, but rather because smallholders have contracted for facilities costs more efficiently than the internalised growing facilities maintained by the company estates. Smallholder sugarcane growers, moreover, operating under the umbrella of a farmers' association in Swaziland, were apparently able to overcome the lumpiness of capital inputs. The conclusion that smallholder production is as efficient as larger suppliers, however, must be weighed with the fact that agribusiness incurred high levels of start-up cost in order to develop this capacity and the question remains whether or not this expense can be recouped. Finally, the results can be used to identify why there are production cost differentials with respect to the same cost elements of the different farmer categories or, secondly, they can be used to indicate specific inefficiencies in smallholder or company production systems. The high level of overhead cost in the company estates, for instance, could prompt the need to rather contract for support facilities instead of incorporating them in the company hierarchy.

The results of the case study, with respect to the second research question, demonstrated that small-scale farmers generate higher levels of transaction cost than larger growers. This conclusion is overwhelmingly supported in the literature as discussed in Section 2.3. Whilst the sugar industry suggested this differential cost was mainly confined to the start-up and administration activities, the timber case study indicated that smaller growers generated differential cost in all stages of the growing operation. The usefulness of the results is that they can be used as a basis to reduce agribusiness cost by way of installing costing systems $(A B C)$ that trace differential cost to the respective category of grower in order to apply for government subsidies, tax cuts or donor assistance. Alternatively, this differential 
cost can be charged back to the respective farmer groups. In the case studies, for instance, the incremental administration cost of dealing with smaller suppliers could be charged back to suppliers as a service fee. In this instance the cost pool in the agribusiness accounts would be the costs of the administration department and the cost driver could be the number of accounting transactions performed. The two sugar companies in the case study are both currently installing activity based costing (ABC) systems. This will, hopefully, allow them to firstly identify incremental transaction cost before some type of decision is made with respect to the differential cost of all the activities in the sugarcane supply chain. In all instances the differential cost established using an $A B C$ costing system can be used as a basis to apply for relief to government or charge the amount back.

The results of the case studies, largely, suggest that contracting can be used as an institution to assist smallholders to overcome the barriers of entry to high value cash crop sectors. The results of the case study would also be useful to agribusiness with respect to acquiring a better understanding of the process and costs involved. Smallholder contracting projects often involve many years of agribusiness inputs before supply commences. In certain instances, moreover, agribusiness is drawn into protracted equity issues involving a local community. The study identifies some of the pitfalls and hidden costs that agribusiness integrators can incur when embarking on small-scale contracting projects. The timber case study, in particular, is indicative of the difficulties of managing large numbers of micro farmers that appear to be unable to be consolidated as an economic entity. The withdrawal of the integrator financed management structure, in this instance, would result in the collapse of the project and the question needs to be asked, whether or not, the micro farmers have really overcome the barriers of entry, on a permanent basis, to the timber growing industry. Contracting projects, ideally, should result in the establishment of permanent growers that operate as viable business entities. Whilst support in the start-up phase is a necessary pre-requisite to overcoming the barriers of entry, the contracted farmers need to be weaned out of the company structure on a long term basis. Finally, the conclusions of the paper should be supported by further related research that could be expanded to include a wider range of raw commodities, as well as studjes that quantify the transaction cost benefits of smallholders operating under the umbrella of a farmers' association. The limitations of this study are that only a few raw commodity supply chains in Southern Africa bave inchuded large numbers of smallholders, as well as maintain the necessary data for these activities.

\section{RECOMMENDATIONS}

A series of general proposals to reduce the transaction cost of smallholder supply can be developed on the basis of the lessons developed in Section 2.3 and the results of the case studies. The reduction of transaction cost in small-scale supplier chains is cited as a fundamental problem in the literature (Runsten \& Key, 1996; Key \& 
Runsten, 1999). In order to reduce transaction cost it is suggested that agribusiness should install sophisticated costing systems, encourage the formation of farmers associations and ensure that the raw commodity characteristics are suited to smallholder production systems.

\section{The installatlon of $A B C$ costing systems}

The use of activity based costing (ABC) systems is recommended. In the case studies many smallholder costs were located in general overhead accounts that were not traced to suppliers because the costing systems were unable to manage this or, alternatively management was reluctant to highlight this cost. $\mathrm{ABC}$ costing can be used to determine the differential use of company resources for agribusiness smallholder growing-delivery and administration transactions. It is recommended that this cost is included in a service charge similar to the banking industry. This incremental cost should be charged back to the supplier as a basis to prompt small farmers to organise their activities more cost effectively under the umbrella of a collective association.

\section{The formation of farmers' associations}

Agribusiness can promote the successful operation of a farmers' association by acquiring representation in the management structure, as well as allowing the association to be represented in its own management structure. Swaziland farmers associations in the sugar industry, for instance, are represented in the factory cane supply committee. Agribusiness, moreover, can further influence the efficiency of the farmers association by ensuring this body maintains records, has no political agenda, is limited in size and contains sufficient professional management. The problems of smallholder representation and high transaction cost can then be addressed through a farmers association.

In the case studies start-up cost was excessive because, mostly, farmers associations were only formed after the individual farmers began supplying the respective companies. Start-up costs of R 600000 , for instance, were recorded with respect to a fifty family sugarcane supplier in the Swaziland case study whilst the Transvaal Sugar company has an annual budget of $\mathbf{R} 3$ million to initiate new projects. These costs could possibly have been reduced by forming a farmers association at the outset. The agribusiness partner could then liase with the farmers association rather than each individual farmer with respect to the start up activities of screening, contract development and training. The lack of a farmers association in the timber case study can be strongly linked to the $\mathbf{R} 10$ million start-up cost incurred by Sappi Forest Division. 
A farmers association can be used to reduce the transaction cost of supply. The growing transactions, for instance, in the sugarcane case study are largely coordinated by their farmers association and both the Swaziland and South African companies confront low levels of transaction cost for this activity. Conversely, in the Timber case study very high levels of transaction cost are incurred and each grower, occupying less than a hectare, receives between 3.7 and 6.5 visits per annum. Clearly this high level of cost needs to be undertaken by a farmers association. The farmer association could also be used as a way to deliver agribusiness quality requirements and inputs including training, extension, technology acquisition, the provision of commodity inputs and the co-ordinating of harvesting-delivery schedules.

More specifically a farmers association reduce the cost of screening, improve the logistics of supply and induce higher levels of asset specificity.

\section{Screening of applicants}

Screening costs, involving large numbers of applicants, can be significantly reduced if these activities are assisted by a representative farmers' association or if agribusiness contracts with the farmers' association, rather than the individual farmer. The careful screening-identification of future partners is a key success factor. Farmers who have a record of previous interaction with agribusiness, appear to be more successful contracting partners (Levin, 1988; Porter \& Phillips-Howard, 1997a; 1997b). The case studies all appear to have developed a data bank of farmer details for each prospective new farmer. In the case of the sugar industry, the screening process took more cognisance of the entrepreneurial ability of the prospective applicant, whereas, in the timber industry, it would appear as if a majority of applicants with land were accepted. The benefits of screening can be increased if the process includes a business aptitude test, a credit check and a list of assetscollateral. The screening process could also capture the location, logistics and communication channels of the applicant in order to ascertain the spatial dynamics of the project.

\section{Logistics of supply}

The design of the logistics of small-scale farm supply is a crucial success factor. Agribusiness, at the outset, can evaluate the transaction frequency of visits, inputs and farmer deliveries with the distances involved, the nature of the roads and the available communication system. An activity based costing (ABC) system should be used that could include the major activities as a series of cost pools. These cost pools could include start-up activities, training-land preparation, growing tending, harvesting-delivery and administration. The quantification of the logistics could also be supported by logistics software that can assemble and program the transaction 
cost of logistics by capturing the spatial dispersion of the farmers, the number of transactions and the average distance to the processor.

The transaction cost of logistics can be fundamentally reduced by allowing a farmers association to provide the necessary inputs, as well as organise the logistics of small-scale supply. The timber case study suggests Sappi Forest should contract with a farmers association for an aggregated monthly volume of timber instead of contracting individually with the 7100 micro farmers. Agribusiness can also improve efficiency by establishing the suitability of the roads, access and communication systems of the proposed project. The timber case study indicated that certain areas were impassable in the wet season and that declining levels of rural security and high levels of ethnic conflict have resulted in a lack of access, except for local community members.

\section{Mutual asset specificity}

The creation of mutual asset specificity reduces uncertainty and raises the exit costs of both sets of contracting partners. The case studies in the sugar and timber industries indicate that the agribusiness partner is confronted with significantly higher levels of asset specificity than the contracted farmers. The industry and site specific processing assets, in the sugar and timber case studies, were valued at $\mathbf{R} 2$ 2.3 billion and $\mathrm{R} 5$ billion respectively. Conversely, the contracted farmers owned fewer assets that were of a more general nature. Mutual asset specificity can be pursued by way of farmers' associations undertaking the purchase of industry specific capital inputs. The Swaziland sugar farmers' associations appear to have increased mutual asset specificity by investing in sugar specific plant and equipment that are too lumpy for the individual farmer. Agribusiness can attempt to act as a facilitator of finance, in this regard, to increase the interlocking nature of the arrangement. Agribusiness can examine other ways of influencing mutual asset specificity by way of configuring the technology of the grower-processor operations in such a way that only the company possesses the technology to perform a specific element of the growing operation. Contracted growers, for instance in the processed tomato sector, require specific harvesting technology that is often owned and operated by agribusiness (Rehber, 1998).

\section{Commodity characteristics}

Certain commodity characteristics are better suited to smallholder supply. Crops, in particular, that are labour intensive in the growing operation and display economies of scale in processing, are more suited to smallholder contracting (Delgado, 1999). The case studies in the sugar and timber industries did not demonstrate particular growing economies for smallholder family labour, yet these growers, mostly matched larger growers with respect to the cost efficiency of production. The reason 
for this ability to compete with larger growers appears to stem from the avoidance of overhead cost rather than the productivity of family labour. Commodities that are perishable will require higher levels of co-ordination cost than those that can be stockpiled. The inappropriate choice of technology, a function of the commodity characteristics, has also been cited as a cause of project failure (Gittinger, 1982).

\section{ACKNOWLEDGEMENT}

The authors would like to thank Prof M Negash, School of Accountancy, Wits University, for his assistance.

\section{REFERENCES}

Anthony, R.J. and Govindarajan, V. (2001). Management Control Systems. Prentice Hall

Argyres, N. (1996). Evidence of the role of firm capabilities in vertical integration decisions. Strategic Management Journal, Feb, 17(2):129 (22).

Bamey, J.B. and Ouchi, W.G. (1988). Organization Economics. Eds. J.B. Barney and W.G. Ouchi, Jossey-Bass Publishers, San Francisco

Barry, P.J., Sonka, S.T. and Lajili, K. (1992). Vertical coordination, financial structure, and the changing theory of the firm, American Journal of Agricultural Economics, 74:1219-25.

Binswanger, H.P. and Elgin, M. (1990). Reflections on Land Reform and Size. Agricultural development in the third world. John Hopkins University Press, Baltimore.

Binswanger, H.P., Deininger, K., and Feder, G. (1993). Power, distortions, revolt and reform in agricultural land relations. World Bank Discussion Paper, Washington, D.C.

Boehlje, $M$ and Doering, $O$. (2000). Farm policy in an industrialized agriculture, Journal of Agribusiness, 18(1):53-60, Special Issue, (March).

Burns, J and Scapens, R.W. (2000). Conceptualizing management accounting change: an institutional framework, Management Accounting Research, 11(1):3-27.

Carter, M.R. and Mesbah, D. (1993). Can Land reform mitigate the exclusionary aspects of rapid agro-export growth? World Development. Vol. 21 (June) 
Carter, M.R. and Wiebe, K. (1990). Access to capital and its impact on agrarian structure and productivity, American Journal of Agricultural Economics, (December).

Delgado,C. (1999). Sources of growth in smallholder agriculture in sub-Saharan Africa: The role of vertical integration of smallholders with processors and marketers of high value-added items, Agrekon, 38:165-189, Special Issue.

Drury, C. (1996). Management and Cost Accounting. International Thomson Business Press.

Drury, C. and Tayles, M. (1998). Cost system design for enhancing profitability. Management Accounting Research, Jan, 76(1):40(3).

Eicher, C.K. and Staatz, J.M. (1998). Agricultural transformation and rural economic development: Introduction. International Agricultural Development. The John Hopkins University Press, Baltimore.

Fenyes, T.I., van Zyl, J. and Vink, N. (1988). Structural imbalances in South African agriculture, The South African Journal of Agricultural Economics, 56:2:181194.

Frank, S.D. and Henderson, D.R. (1992). Transaction costs as determinants of vertical co-ordination in the U.S. food industries, American Journal of Agricultural Economics, 74(4):941-950.

Gittinger, J.P. (1982). Economic Analysis of Agricultural Projects. John Hopkins University Press, Baltimore, Maryland.

Glover, D. (1994). Contract farming and commercialization of agriculture in developing countries. In: Von Braun, J. and Kennedy, E. (eds.) Agricultural commercialization, economic development and nutrition. Baltimore,MD: The John Hopkins University Press.

Han, K.H. (1991). A productivity measurement of activities at the micro level. Management Accounting Research, 2(4), (December).

Haggblade, S. (1987). Vertical considerations in Choice-of-Technique Studies: Evidence from Africa's Indigenous Beer Industry. Economic Development and Cultural Change, 723-739.

Horngren, C.T., Foster, G., Datar, S.M., and Uliana, E. (1999). Cost Accounting in South Africa. Prentice Hall South Africa 
Ittner, C. D. and Larckner, D.F. (1998). Innovations in performance measurement: Trends and research implications. Journal of Management Accounting Research, (10): 205-238.

Kandiwa, V. (1999). Economic performance of smallholder farmers using alternative vertical coordination mechanisms for horticultural crops. MS thesis, Department of Agricultural Economics, Cornell University.

Kaplan, R.S., and Atkinson, A.A. (1998). Advanced Management Accounting, $3^{\text {rd }}$ Edition, Prentice Hall International, New Jersey.

Kaplan, R.S. and Norton, D.P. (1992). The balanced scorecard-measures that drive performance. Harvard Business Review, January-February, pp 71-79

Key, N. and Runsten, D. (1999). Contract farming, small-holders, and Rural Development in Latin America: The organization of agroprocessing firms and the scale of outgrower production. World Development Vol. 27 No 2: 381-401.

Kirsten, J. and Sartorius, K. (2002). Linking agribusiness and small-scale farmers in developing countries: Is there a new role for contract farming? Development Southern Africa, Vol.17, No. 4, (October).

Kirsten, J. and van Zyl, J. (1996). The contemporary agricultural policy environment: undoing the legacy of the past. Agricultural Land Reform in South Africa, Oxford University Press, Cape Town.

Langfield-Smith, K. and Smith, D. (2003). Management control systems and trust in outsourcing relationships. Management Accounting Research, 14(3):281-307, September.

Levin, R. (1988). Contract farming in Swaziland: Peasant differentiation and the constraints of land tenure, African Studies 47(2):101-120.

Ling, K.C., and Liebrand, C.B. (1995). Vertical integration patterns of dairy co-ops reflect changing market, Farmer Cooperatives, 62(6):1-8, September.

Little, P.D. (1994). Contract farming and the development question. In: Little, P.D. and Watts, M.J. (eds.) Living under contract. Madison: University of Wisconsin Press.

Little, P.D. and Watts, M.J. (1994). Living under contract. Madison: University of Wisconsin Press. 
Livio, C. and Massimo, G. (2002). The efficiency measurement of factories via data envelopement analysis, Systems Analysis Modelling Simulation. 42(1):1521, 16, October.

Machethe, C. Reardon, T., and Mead, D.C. (1997). Promoting farm/non-farm linkages for employment of the poor in South Africa: A research agenda focused on small-scale farms and agro-industry, Development Southern Africa. 14(3), October.

Mbonga, M., van den Brink, R. and van Zyl, J. (1990). Evolution of the agrarian structure in South Africa, Agricultural Land Reform in South Africa, Oxford University Press, Cape Town.

Merchant, K.A. (1998). Modern Management Control Systems, Prentice Hall, New Jersey.

Ministry For Agriculture and Land Affairs. (1998). Agricultural Policy in South Africa: A discussion document. National Department of Agriculture, CTP Book Printers, ISBN 0-621-28815-2, Cape Town

Pasour, E.C. (1998). The potential impact of increased vertical integration on North Carolina grain farmers North Carolina State University, December, http://www.ncsoy.org/pasour2.htm

Porter, M. (2001). Strategy and the internet, Harvard Business Review, March.

Porter, G, and Phillips-Howard, K. (1997a). Contract farming in South Africa: A case study from KwaZulu-Natal, Geography: Journal of the Geographical Association, 82(354): 1-38, January.

Porter, G and Phillips-Howard, K. (1997b). Comparing contracts: An evaluation of contract farming schemes in Africa, World Development, 25:227-238.

Reardon, T. and Barrett, C.B. (2000). Agroindustrialization, globalization, and international development: An overview of issues, patterns, and determinants. Agricultural Economics, 23:195-205, Special issue, September.

Rehber, E. (1998). Vertical integration in agriculture and contract farming. Regional Research Project NE-165: Private Strategies, Public Policies, and Food System Performance, University of Massachusetts, Dept. of Resource Economics, Amherst, MA 01003

Rhodes, V.J. (1993). Industrialization of agriculture: Discussion, American Journal of Agricultural Economics, 75(5):1137-1140. 
Rouse, P., Putterill, M, and Ryan, D. (2002). Integrated performance management design: insights from an application in aircraft maintenance, Management Accounting Research, 13:229-248.

Runsten D. and Key, N. (1996). Contract farming in developing countries: Theoretical aspects and analysis of some Mexican Cases. Research Report No. 3, August 1996. Report prepared for the United Nations Economic Commission for Latin America and the Caribbean, Santiago, Chile.

Schrader, L.F. (1986). Responses to forces shaping agricultural marketing: Contracting, American Journal of Agricultural Economics. 68 (5):1161 - 1167.

Sofranko,A.; Frerichs, R.; Samy, M. and Swanson, B. (2000). Will farmers organize?: Structural change and loss of control over production. http://web.aces.uuiuc.edw/value/research/organize.htm

Spekle, R.F. (2001). Explaining management control structure variety: a transaction cost economics perspective, Accounting, Organizations and Society, 25(4/5):419, $23 p$

Stanton, J.V. (2000). The role of Agribusiness Development: Replacing the diminished role of the government in raising rural incomes. Journal of Agribusiness, 18 (2):173-187. Spring.

Van den Bogaard, M.A. and Spekle, R.F. (2003). Reinventing the hierarchy: strategy and control in the Shell Chemicals carve-out, Management Accounting Research, $14: 79-93$

Van der Meer-Kooistra, J. and Vosselman, Ed G.J. (2000). Management control of interfirm transactional relationships: The case of industrial renovation and maintenance. Accounting, Organizations and Society, 25(1):51, 27.

Van Rooyen, J. (1999). Agricultural partnership schemes as a mechanism for transformation and development. Paper presented at the $3^{\text {rd }}$ regional conference of Initiative for the Development and Equity in African Agriculture (IDEAA), Durban.

Van Rooyen, C.J., Ngqangweni, S. and Sartorius, K. (1999). Agribusiness partnership schemes as a mechanism for participation, transformation and development. Proceedings of $33^{\text {rd }}$ Conference of the South African Society for Agricultural Extension, 11-13 May, Bloemfontein, South Africa

Van Zyl, J.(1996). The farm size efficiency relationship, Agricultural Land Reform in South Africa, Oxford University Press, Cape Town. 
Van Zyl, J. and Kirsten, J. (1999). Approaches and progress with land reform in South Africa. Agrekon, 38:326-342, May-June.

Van Zyl, J., Kirsten, J. and Binswanger, H.P. (1996). Introduction. Agricultural Land Reform in South Africa. Oxford University Press, Cape Town.

Von Braun, J. (1990). Introduction and Overview. In Agricultural Commercialisation, Economic Development and Nutrition. Eds Joachim von Braun and Eileen Kennedy, John Hopkins University Press, London.

Von Braun, J. and Kennedy, E. (1994). Agricultural Commercialisation, Economic Development and Nutrition. John Hopkins University Press, London

Watts, M.J. (1994). Life under contract; Contract farming, Agrarian Restructuring, and Flexible Accumulation. In. Peter D. Little and Michael. J. Watts (eds.) Living Under Contract. The University of Wisconsin Press, Madison.

Widener, S.K. and Selto, F.H. (1999). Management control systems and boundaries of the firm: Why do firms outsource internal auditing activities? Journal of Management Accounting Research, 11:45, 29.

Wheelock, D.C. and Wilson, P.W. (1995). Evaluating the efficiency of commercial banks: Does our view of what banks do matter? Review (Federal Reserve Bank of Saint Louis), Jul/Aug, Vol. 77, Issue 4.

Williamson, O.E. (2000). The new institutional economics: taking stock, looking ahead, Journal of Economic Literature. XXXVII:595-613, (September). 